\title{
Comparison of Organic Constituents Found in the Condensed and Vapor Phases of Tanks 241-BY-108, 241-BY-110, and 241-C-102
}

\author{
J. L. Huckaby
}

J. A. Glissmeyer

Pacific Northwest National Laboratory

J. E. Meacham

L. A. Stauffer

Westinghouse Hanford Company

Date Published

September 1996

Prepared for the U.S. Department of Energy Assistant Secretary for Environmental Management

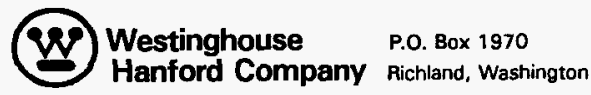

Management and Operations Contractor for the

U.S. Depertment of Energy under Contrect DE-AC06-87RL 10930

Approved for public release; distribution is unlimited 
LECAL DISCLAMMER

This report was prepered as an eccount of work sponsored by an agency of the United Statos Governmont. Neither the United States Government nor any egeney thereof, nor any of their employees, nor any of thair contractors, aubcontractors or their amployoes, makes any werrenty, exprese or implied, or asaumes any logel liability or reeponeibility for the accuracy, completeness, or any thind party's use or the results of such uso of any information, epparatus, product, or process disclosed, or represents that its use would not infringe privately owned rights. Reference herein to any epecific commercial product, process, or service by trade neme, tredemark, manufacturer, or otherwise, does not necessarily constitute or imply its endoreement, recommendation, or favoring by the United States Government or any egoncy thereof or its contractors or subcontractore. The viewe and opinions of authors expressed herein do not necesserily state or reflect those of the United States Government or any agency thereof.

This report has been reproduced from the best evailable copy. Availebie in peper copy snd microfiche.

Available to the U.S. Department of Energy

and its contractors from

U.S. Department of Energy

Office of Sciontific and Technical informetion (OST))

P.O. Box 62

Oak Ridge, TN 37831

(615) 576-8401

Aveilable to the public from the U.S. Department of Commerce National Technicel information Service (NTIS)

5285 Port Royal Roed

Springfield, VA 22161

(703) $487-4650$

Printed in the United States of America

DISCLM-1.CHP (8-95) 


\section{RELEASE AUTHORIZATION}

Document Number: WHC-EP-0919, Rev. 0

Comparison of Organic Consituents Found in the

Document Title: Condensed and Vapor Phases of Tanks 241-BY-108, 241BY-110, and 241-C-102

Release Date: $\quad 9 / 27 / 96$

This document was reviewed following the procedures described in WHC-CM-3-4 and is:

APPROVED FOR PUBLIC RELEASE

WHC Information Release Administration Specialist:

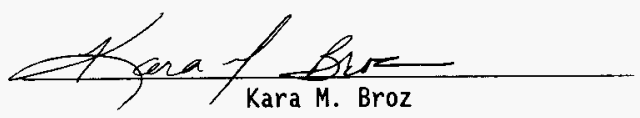

September 27, 1996 


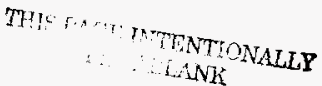




\section{COMPARISON OF ORGANIC CONSTITUENTS FOUND IN THE CONDENSED AND VAPOR PHASES OF TANKS 241-BY-108, 241-BY-110, AND 241-C-102}

\section{SUMMARY}

Results from vapor and condensed-phase sampling of tanks 241-BY-108, 241-BY-110, and 241-C-102 were reviewed and compared in this report. Both vapor and condensed-phase samples from tanks 241-BY-108 and 241-C-102 indicate the presence of organic solvent. The organic solvent remaining in these tanks are predominantly the heavier fractions of normal paraffin hydrocarbons (NPHs) (i.e., dodecane, tridecane, and tetradecane) and tributyl phosphate (TBP). As was found for the organic solvent in tank 241-C-103, the flash point for the 241-BY-108 and 241-C-102 organic solvent is well above current tank temperatures.

Differences between the measured headspace organic vapor concentrations and the organic vapor concentrations estimated from condensed-phase data indicate that the tank headspaces are not in equilibrium with the organic solvent detected in the waste. Non-equilibrium is the result of air flow through these tanks from passive ventilation. This is important because an equilibrium difference allows calculation of effective organic pool size in the tanks.

Calculations based on estimated tank ventilation rates and headspace characterization data indicate that tanks 241-BY-108 and 241-C-102 contain significant amounts of organic solvent (i.e., more than a $1 \mathrm{~m}^{2}$ pool). Tank $241-\mathrm{BY}-110$ core samples did not contain measurable quantities of NPHs or TBP, though the semivolatile NPHs were observed in tank headspace samples. The total effective surface area of organic solvent in tank 241-BY-110 is estimated to be less than $1 \mathrm{~m}^{2}$; consequently, this tank was not anticipated to contain a significant amount of solvent.

An additional observation from the comparison of vapor and condensed-phase sample data is that headspace vapor sampling can detect the presence of organic solvent, even if a surface pool does not exist. Analyses of condensed-phase samples from tank 241-BY-108 show no organic solvent in the top $50 \mathrm{~cm}$ of waste. However, the sample segments below $50 \mathrm{~cm}$ show NPH and some TBP. This is significant in that vapor sampling can detect solvent which is on the surface or entrained in the waste. 
WHC-EP-0919

This page intentionally left blank. 


\section{TABLE OF CONTENTS}

1.0 INTRODUCTION $\ldots \ldots \ldots \ldots \ldots \ldots \ldots \ldots \ldots \ldots \ldots \ldots \ldots \ldots \ldots$

2.0 SAMPLE DESCRIPTION $\ldots \ldots \ldots \ldots \ldots \ldots \ldots \ldots \ldots \ldots \ldots \ldots$

2.1 VAPOR PHASE SAMPLES $\ldots \ldots \ldots \ldots \ldots \ldots \ldots \ldots \ldots$

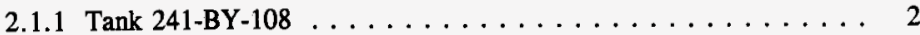

2.1.2 Tank $241-B Y-110 \ldots \ldots \ldots \ldots \ldots \ldots \ldots \ldots \ldots \ldots$

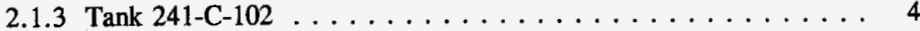

2.2 CONDENSED PHASE SAMPLES $\ldots \ldots \ldots \ldots \ldots \ldots \ldots \ldots$

2.2.1 Tank $241-\mathrm{BY}-108 \ldots \ldots \ldots \ldots \ldots \ldots \ldots \ldots \ldots \ldots \ldots$

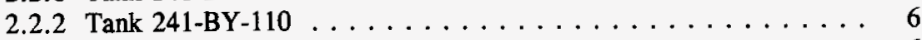

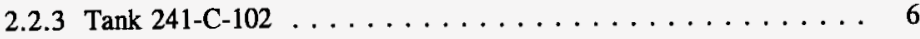

3.0 COMPARISON OF VAPOR AND CONDENSED PHASE SAMPLING

RESULTS $\ldots \ldots \ldots \ldots \ldots \ldots \ldots \ldots \ldots \ldots \ldots \ldots \ldots$

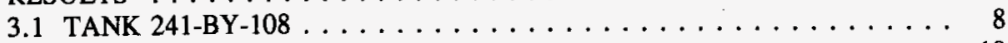

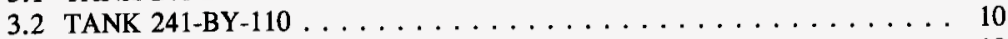

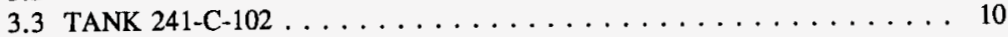

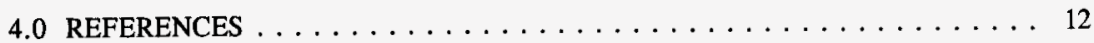




\section{LIST OF TABLES}

2-1 Tank 241-BY-108 Organic Compounds in Vapor Samples (Mean Values) . . . . 3

2-2 Tank 241-BY-110 Organic Compounds in Vapor Samples (Mean Values) . . . . . 4

2-3 Tank 241-C-102 Organic Compounds in Vapor Samples (Mean Values) $\ldots \ldots \ldots 5$

2-4 Tank 241-BY-108 Organic Compounds in Core Sample (Mean Values) . . . . . . 6

2-5 Tank 241-C-102 Organic Compounds in Upper Fraction of Auger Sample ... . . 7

2-6 Tank 241-C-102 Organic Compounds in Lower Fraction of Auger Sample . . . . . 7

3-1 Tank 241-BY-108 -- Comparisons $\ldots \ldots \ldots \ldots \ldots \ldots \ldots \ldots \ldots$

3-2 Tank 241-C-102 Upper Section -- Comparisons $\ldots \ldots \ldots \ldots \ldots . \ldots \ldots$

3-3 Tank 241-C-102 Lower Section -- Comparisons . . . . . . . . . . . . . 12 


\section{LIST OF TERMS}

ITS

NPH

ORNL

PNNL

ppmv

PUREX

TBP

TST

VSS

WHC
In Tank Solidification

normal paraffin hydrocarbon

Oak Ridge National Laboratory

Pacific Northwest National Laboratory

parts per million by volume

Plutonium Uranium Extraction

tributyl phosphate

triple sorbent trap

vapor sampling system

Westinghouse Hanford Company 
WHC-EP-0919

This page intentionally left blank. 


\subsection{INTRODUCTION}

Historical production of weapons grade plutonium at the Hanford Site involved various organic liquid chemical separation processes. Organic extractants and solvents associated with these separation processes are known to have been sent to the high level radioactive waste storage tanks at the Hanford Site. Their presence in the tanks has been determined to be a safety issue.

The 241-C tank farm is known to have directly received Plutonium Uranium Extraction (PUREX) Plant organic waste (Sederburg and Reddick 1994). This waste contained the extractant TBP used in the PUREX process, in a solution of semivolatile diluents. Different diluent mixtures were used during the 16 year life of the PUREX process, but for chemical inertness, the semivolatile NPHs were the preferred, and most common, diluent constituents. Waste transfers from the 241-C tank farm during the late 1950s and early 1960s apparently resulted in the transfer of much of this waste to the 241-BY tank farm. Schultz (1968) reported the presence of a layer of TBP and NPHs floating on other waste in tank 241-BY-112. The organic waste in tank 241-BY-112 was apparently removed by steam distillation during the In Tank Solidification (ITS) process (Huckaby and Bratzel 1995a). A similar organic liquid was reported by Anderson (1969) as a $25-\mathrm{cm}$ to $35-\mathrm{cm}$ deep layer in tank 241-C-102 in 1969. Waste transfers from tank 241-C-102 to tank 241-C-103 in 1975 are thought to have transferred the bulk of the NPHs and TBP to tank 241-C-103, and left residual quantities in tank 241-C-102 (Carothers 1988).

Tank waste auger and core samples have identified semivolatile NPHs in tanks 241-BY-108 and 241-C-102, as well as TBP. Vapor samples from the headspaces of these tanks also indicate they contain NPHs and TBP. This report examines the data from the vapor and condensed-phase samples and comments on apparent agreements and disagreements of these data.

\subsection{SAMPLE DESCRIPTION}

\subsection{VAPOR PHASE SAMPLES}

The primary vapor-phase data used in this report are based on samples collected using the Vapor Sampling System (VSS). Validation of the VSS for tank headspace sampling has been described by Mahon et al. (1996) and Huckaby et al. (1996). Details of its use to sample tanks 241-BY-108, 241-BY-110, and 241-C-102 are given in WHC 1995a, 1995b, and 1995 c, respectively. 
Organic vapor samples were collected in SUMMA ${ }^{1}$ canisters and triple sorbent traps (TST). SUMMA $^{\mathrm{TM}}$ canisters were analyzed by Pacific Northwest National Laboratory (PNNL), and TSTs were analyzed by Oak Ridge National Laboratory (ORNL). Analyses involved sample conditioning steps unique to each laboratory, but all analyses were based on gas chromatography for chemical separation and mass spectroscopy for identification and quantitation of constituents.

Vapor-phase TBP results are believed to be biased low. Adsorption of TBP by both the stainless steel components of the VSS and by the glass fiber filters used to remove radioactive particles from the sample air is believed to have interfered with quantitative transfer of TBP vapors in the VSS. Furthermore, the stainless steel SUMMA ${ }^{\mathrm{TM}}$ canisters are inappropriate for sampling TBP. Jenkins et al. (1995a) reports preliminary testing performed to address TBP sample transfer.

Tank headspace characterization summary reports containing information on the sampling events, sample analyses, and references for the analytical reports have been issued for each of the three tanks discussed here (Huckaby and Bratzel 1995b, 1995c, and 1995d).

\subsubsection{Tank 241-BY-108}

The headspace of tank 241-BY-108 has been sampled five times since March 1994. The initial samples, collected in March 1994, contained very high levels of organic vapors, and indicated that tank 241-BY-108 might contain appreciable quantities of NPHs and TBP. More extensive vapor sampling in October 1994 confirmed this, and provided quantitative concentrations for many individual organic vapors (Huckaby and Bratzel 1995b). Of the approximately 80 waste tanks that have been vapor sampled to date, only tank 241-C-103 has been found to have a higher level of organic vapors than tank 241-BY-108. Vapor samples from tank 241-BY-108 were also collected in January, March, and September 1996 as part of a study to assess temporal headspace composition changes. Results from the January 1996 sampling event have been published (Huckaby et al. 1996), but only preliminary results are available from the March 1996 event, and no results are yet available from the September 1996 event.

The dominant organic vapors detected in tank 241-BY-108 are the NPHs, semivolatile branched and cyclic alkanes, and their associated degradation products. TBP was not detected; rather, a hydrolysis product of TBP, 1-butanol, was the single most abundant organic compound. Table 2-1 lists mean vapor-phase concentrations of the NPHs and TBP reported by PNNL and ORNL. Huckaby and Bratzel (1995b) have summarized the March 1994 and October 1994 sampling events, and have compiled the analytical results.

\footnotetext{
${ }^{1}$ Trademark of Molectrics, Inc., Cleveland, Ohio.
} 
Table 2-1. Tank 241-BY-108 Organic Compounds in Vapor Samples (Mean Values)

\begin{tabular}{|c|c|c|}
\hline 将 & 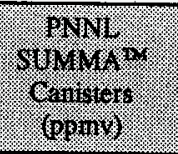 & 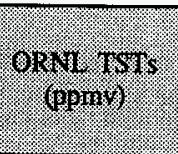 \\
\hline n-Nonane & 0.14 & 0.19 \\
\hline n-Decane & 0.09 & 0.21 \\
\hline n-Undecane & 0.48 & 0.48 \\
\hline n-Dodecane & 0.81 & 0.80 \\
\hline $\mathrm{n}$-Tridecane & 0.64 & 0.73 \\
\hline n-Tetradecane & 0.22 & 0.97 \\
\hline n-Pentadecane & n.d. & 0.33 \\
\hline n-Hexadecane & n.d. & 0.005 \\
\hline Tributyl Phosphate & n.a. & n.d. \\
\hline
\end{tabular}

n.a. = not applicable

n.d. $=$ not detected

\subsubsection{Tank 241-BY-110}

Headspace samples from tank 241-BY-110 were collected in November 1994. The level of organic vapors in tank 241-BY-110 was found to be higher than for most other tanks, though much lower than that of tank 241-BY-108. The calculated equivalent pool size for tank 241-BY-110 is less than $1 \mathrm{~m}^{2}$ (Cowley and Postma 1996). The semivolatile NPHs, related branched and cyclic alkanes, and many volatile species that have been attributed to the degradation of NPHs and TBP account for nearly all detected organic vapors. Like tank 241-BY-108, the concentration of organic vapors in tank 241-BY-110 is substantially higher than in the tank to which it is connected (via cascade piping). This indicates the vapors are indeed evolved by the waste in tank 241-BY-110.

Table 2-2 lists mean vapor-phase concentrations of the NPHs and TBP reported by PNNL and ORNL. Huckaby and Bratzel (1995c) have summarized the November 1994 sampling event and compiled the analytical results. 
Table 2-2. Tank 241-BY-110 Organic Compounds in Vapor Samples (Mean Values)

\begin{tabular}{|c|c|c|}
\hline 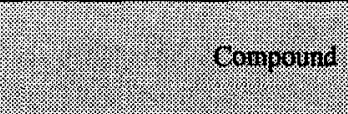 & 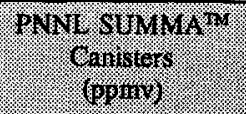 & 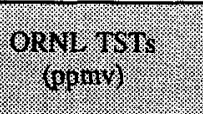 \\
\hline n-Nonane & 0.035 & 0.030 \\
\hline n-Decane & 0.032 & 0.024 \\
\hline n-Undecane & 0.053 & 0.042 \\
\hline n-Dodecane & 0.071 & 0.079 \\
\hline n-Tridecane & 0.058 & 0.130 \\
\hline n-Tetradecane & 0.028 & 0.045 \\
\hline n-Pentadecane & n.d. & 0.017 \\
\hline n-Hexadecane & n.d. & 0.022 \\
\hline Tributyl Phosphate & n.a. & n.d. \\
\hline
\end{tabular}

n.a. = not applicable

n.d. = not detected

\subsubsection{Tank 241-C-102}

Tank 241-C-102 was sampled for gases and vapors in August 1994. Samples contained high levels of the semivolatile NPHs and volatile organic species associated with the degradation of NPHs and TBP. Tank 241-C-102 was observed to have the third highest total organic vapor concentration, being only less than that in tanks 241-C-103 and 241-BY-108.

Table 2-3 lists mean vapor-phase concentrations of the NPHs and TBP reported by PNNL and ORNL. Agreement between the PNNL SUMMA ${ }^{\mathrm{TM}}$ canister and ORNL TST results is very good. Note that ORNL TST results given by Huckaby and Bratzel (1995c) incorporate an early ORNL reporting error, and ORNL values given in Table 2-3 are those of Jenkins et al. (1995b).

Because tanks 241-C-101 and 241-C-103 were ventilated via their cascade piping connections with the tank 241-C-102 headspace at the time of vapor sampling, the tank 241-C-102 headspace composition was a function of the composition and breathing rates of tanks 241-C-101 and 241-C-103. Huckaby and Bratzel (1995d) examined headspace characterization data from these three tanks and concluded that while the data could not be used to confirm the tanks were exchanging gases and vapors, the data did indicate little significant transfer of semivolatile organic species was occurring. However, the headspace of tank 241-C-103 has much higher concentrations of the semivolatile NPHs than tank 
241-C-102, and transfer of these via the cascade line may alter the relative distribution of NPHs in the headspace of tank 241-C-102.

Table 2-3. Tank 241-C-102 Organic Compounds in Vapor Samples (Mean Values)

\begin{tabular}{|c|c|c|}
\hline f & 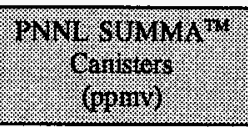 & 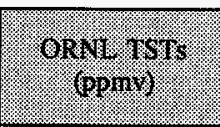 \\
\hline n-Nonane & 0.15 & 0.14 \\
\hline n-Decane & 0.64 & 0.54 \\
\hline $\mathrm{n}$-Undecane & 1.62 & 1.40 \\
\hline n-Dodecane & 1.62 & 1.80 \\
\hline n-Tridecane & 1.46 & 1.30 \\
\hline n-Tetradecane & 0.50 & 1.02 \\
\hline n-Pentadecane & 0.017 & 0.13 \\
\hline n-Hexadecane & n.d. & 0.11 \\
\hline Dibutyl Butylphosphonate & n.a. & 0.00093 \\
\hline Tributyl Phosphate & n.a. & 0.054 \\
\hline
\end{tabular}

n.a. $=$ not applicable

n.d. $=$ not detected

\subsection{CONDENSED PHASE SAMPLES}

\subsubsection{Tank 241-BY-108}

Auger samples extending to a depth of approximately $50 \mathrm{~cm}$ were collected from two locations of the waste crust of tank 241-BY-108 in August 1994. These were subjected to an organic solvent extraction and the extract analyzed for semivolatile organic compounds, but no organic compounds were detected (Campbell et al. 1995).

Rotary mode core samples from tank 241-BY-108 were collected in July and August 1995. Analyses for semivolatile NPHs and TBP were performed by the Westinghouse Hanford Company (WHC) 222-S Laboratory on two of the three core samples. Neither NPHs nor TBP was detected in the first segment of either core, but both were found in lower sections. Table 2-4 lists the mean concentrations of organic compounds found in the core samples; more detailed results are given by Baldwin et al. (1996). 
Table 2-4. Tank 241-BY-108 Organic Compounds in Core Sample (Mean Values)

\begin{tabular}{|c|c|c|c|}
\hline (1. & 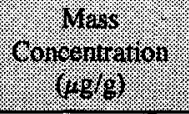 & (6) & 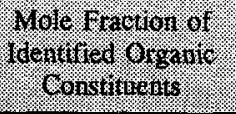 \\
\hline n-Nonane & 0.988 & 0.008 & 0.004 \\
\hline n-Decane & 3.42 & 0.024 & 0.012 \\
\hline n-Undecane & 23.5 & 0.150 & 0.078 \\
\hline n-Dodecane & 58.8 & 0.345 & 0.179 \\
\hline n-Tridecane & 71.3 & 0.387 & 0.200 \\
\hline n-Tetradecane & 55.1 & 0.278 & 0.144 \\
\hline n-Pentadecane & 22.4 & 0.105 & 0.055 \\
\hline Tributyl Phosphate & 0.0745 & 0.00028 & 0.00014 \\
\hline
\end{tabular}

\subsubsection{Tank 241-BY-110}

Nine core samples were collected from tank 241-BY-110 from July to October 1995 (Simpson et al. 1996). All samples were visually inspected for separable organic liquid phase, but none were detected. Analyses for the NPHs and TBP were performed using gas chromatography with flame ionization detection. The procedure involved spiking samples with n-hexadecane as a quality assurance verification of analyte recovery. None of the target analytes were reported above the detection limits, indicating no significant quantities of organic solvent in this tank. However, because of a data reduction error, the surrogate $\mathrm{n}$-hexadecane was reported as a detected waste constituent in the Tank Characterization Report (Simpson et al. 1996).

\subsubsection{Tank 241-C-102}

Tank 241-C-102 was auger sampled in August 1992. No separable organic liquid phase was detected in the drainable liquid obtained from the auger sample. The auger sample was divided into upper and lower fractions, which were analyzed separately for NPHs and TBP (Campbell et al. 1995). Analytes were identified using a gas chromatograph with mass spectroscopic detection, and quantitated using a gas chromatograph with flame ionization detection.

Tables 2-5 and 2-6 list the organic compound concentrations measured in the upper and lower sections, respectively. Results given in Tables 2-5 and 2-6 indicate that while the concentration of NPH in the upper fraction is only about half that in the lower fraction, the distribution of individual NPHs is the same. The similarity between the last columns of 
Tables 2-5 and 2-6 suggests that the NPH and TBP mixtures in the two sample fractions are essentially the same.

Table 2-5. Tank 241-C-102 Organic Compounds in Upper Fraction of Auger Sample

\begin{tabular}{|c|c|c|c|}
\hline 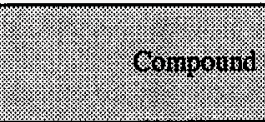 & 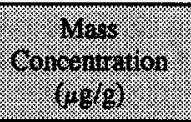 & 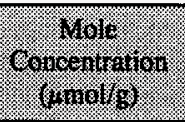 & 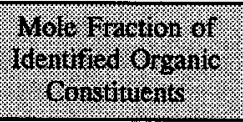 \\
\hline n-Decane & 107 & 0.75 & 0.015 \\
\hline $\mathrm{n}$-Undecane & 553 & 3.54 & 0.068 \\
\hline n-Dodecane & 2050 & 12.0 & 0.23 \\
\hline $\mathrm{n}$-Tridecane & 3500 & 19.0 & 0.37 \\
\hline n-Tetradecane & 1760 & 8.9 & 0.17 \\
\hline Tributyl Phosphate & 2060 & 7.7 & 0.15 \\
\hline
\end{tabular}

Table 2-6. Tank 241-C-102 Organic Compounds in Lower Fraction of Auger Sample

\begin{tabular}{|c|c|c|c|}
\hline - enmpinging & 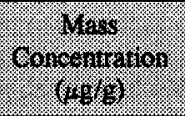 & 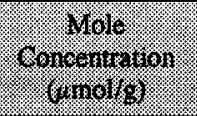 & 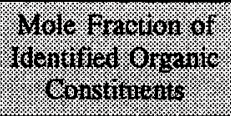 \\
\hline n-Decane & 232 & 1.6 & 0.015 \\
\hline n-Undecane & 1320 & 8.4 & 0.080 \\
\hline n-Dodecane & 4450 & 26.1 & 0.25 \\
\hline n-Tridecane & 7520 & 40.8 & 0.39 \\
\hline n-Tetradecane & 3650 & 18.4 & 0.17 \\
\hline Tributyl Phosphate & 2740 & 10.3 & 0.097 \\
\hline
\end{tabular}




\subsection{COMPARISON OF VAPOR AND CONDENSED PHASE SAMPLING RESULTS}

\subsection{TANK 241-BY-108}

Mean concentrations of organic compounds from tank 241-BY-108 core samples are given in Table 2-4 in three types of units: mass of constituent per mass of sample; moles of constituent per mass of sample; and moles of constituent per total moles of identified organic compounds. The last of these, the mole fraction of identified organic constituents, can be used to estimate the vapor composition above an organic solution consisting of the listed compounds. Assuming activity coefficients for these constituents in the actual waste matrix to be approximately equal, Raoult's law can be used with estimated pure component vapor pressures and the condensed-phase organic mole fractions to estimate the partial pressures of individual constituents. Table 3-1 gives estimated organic vapor concentrations derived from core sample data along with actual tank headspace vapor characterization data. For each constituent listed, the condensed-phase organic mole fraction (second column) is multiplied by its pure component vapor concentration (third column) to obtain a calculated vapor concentration (fourth column). Pure component vapor concentrations were calculated using Antoine's equation ${ }^{2}$ with constants from Dean (1992), Dreisbach (1959), and Schultz and Navratil (1984).

The last three columns in Table 3-1 show the best agreement between vapor and condensedphase organic compound data occurs for the least volatile constituents (n-pentadecane and $\mathrm{n}$-tetradecane) and is worst for the more volatile constituents (n-nonane and n-decane). Specifically, the n-nonane concentration in the tank headspace is more than a factor of 100 lower than predicted by the limited Raoult's law calculation, while the headspace n-pentadecane concentration in TST samples is very close to its predicted value. A plausible explanation for this observation is that the more volatile constituents have been depleted from the organic waste at the surface because of preferential evaporation. This would imply that estimation of organic waste composition from vapor-phase data may overestimate the fraction of low volatility constituents within the waste.

The observed headspace concentrations are significantly lower than that estimated from a Raoult's law calculation using pure component vapor pressures and condensed-phase organic mole fractions. This is reasonable because passive ventilation of the tank prevents establishment of equilibrium between the vapor and condensed-phases. Also, based on characterization of the vapor-phase, there are many other volatile and semivolatile constituents in the waste that were not included in the Raoult's law calculation, and the omission of these causes an over-estimation of the NPH vapor concentrations.

\footnotetext{
${ }^{2}$ Antoine's equation is a three-parameter correlation that approximates the vapor pressure of a pure compound as a function of temperature.
} 
Table 3-1. Tank 241-BY-108 -- Comparisons

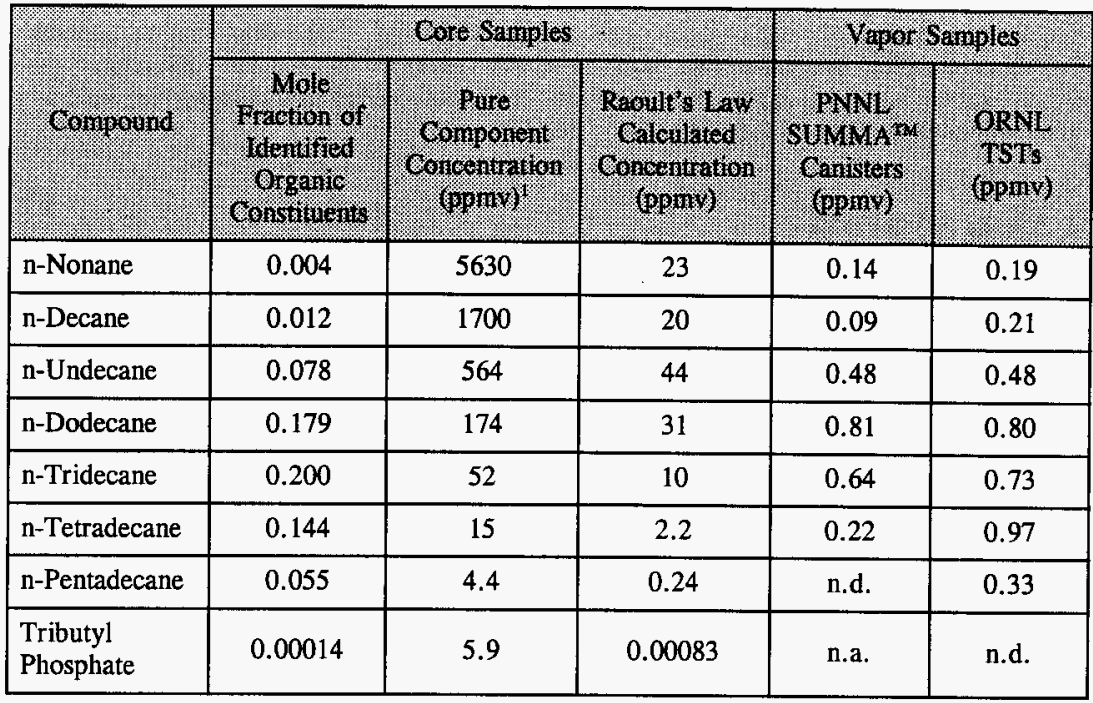

n.a. $=$ not applicable

n.d. $=$ not detected

1 Pure component concentrations were calculated at $25^{\circ} \mathrm{C}$ (the estimated waste surface temperature in tank 241-BY-108) with Antoine equation constants given by Dean (1992) for n-nonane and n-decane, by Dreisbach (1959) for other alkanes, and by Schultz and Navratil (1984) for TBP.

Vapor samples from the January and March 1996 sampling events were found to contain much lower levels of organic vapors than samples from October 1994. This is apparently attributable to the fact that the headspace of tank 241-BY-108 was purged with ambient air in August 1995. At that time, a portable exhauster was installed and operated on tank 241-BY-108 in support of rotary mode core sampling operations. That the headspace vapor concentrations in January 1996 were still much lower than their pre-August 1995 levels indicates that the evolution of vapors from the waste is only slightly faster than the removal of vapors via air exchange with the atmosphere. Consistent with this explanation is the observation that vapor concentrations were measured to be higher in the March 1996 samples than in the January 1996 samples. This slow recovery of the headspace is also consistent with the lack of NPHs and TBP in samples from the waste surface of tank 241-BY-108 (auger samples from the top $50 \mathrm{~cm}$ and the first segment of each core contained no NPHs or TBP). 
Despite indications that the NPHs and TBP reside well below the waste surface in tank 241-BY-108, the level of organic vapors in tank 241-BY-108 identify it as having a total effective surface area of organic liquid waste greater than $1 \mathrm{~m}^{2}$. Even data from the January 1996 vapor sampling event identifies tank 241-BY-108 as exceeding the $1 \mathrm{~m}^{2}$ criterion, despite the fact that the headspace organic vapor concentration had been greatly reduced by active ventilation in August 1995 (Huckaby 1996).

\subsection{TANK 241-BY-110}

While the semivolatile NPHs were identified in vapor samples from tank 241-BY-110, they were not detected in any of the nine core samples. This indicates the presence of only a small amount of solvent, and also suggests that the solvent is not pervasively mixed with the tank waste solids. Though neither the quantity nor location of the organic liquid in tank 241-BY-110 can be determined from vapor sampling data, calculations do indicate that the total effective surface area of an organic solution of NPHs and TBP in tank 241-BY-110 would be less than $1 \mathrm{~m}^{2}$ (Huckaby 1996).

\subsection{TANK 241-C-102}

Analogous to Table 3-1 for tank 241-BY-108, Tables 3-2 and 3-3 compare data on NPHs and TBP from the two fractions of the auger sample from tank 241-C-102 with headspace characterization data. Actual headspace concentrations are lower than that predicted from condensed-phase data, presumably because the vapor and condensed-phases are not at equilibrium. The measured and predicted distributions of NPH vapors are similar, however, in that $\mathrm{n}$-undecane and $\mathrm{n}$-dodecane vapor concentrations are higher than others.

As with the comparison of tank 241-BY-108 data, Tables 3-2 and 3-3 indicate better agreement between predicted and measured vapor concentrations as the volatility of the compound decreases. For example, dividing the NPH vapor concentrations predicted from upper-fraction auger sample data (i.e., values given in the fourth column of Table 3-2) by the ORNL TST headspace results (i.e., values given in the last column of Table 3-2) gives 50 for $n$-decane, 29 for $n$-undecane, 24 for $n$-dodecane, 16 for $n$-tridecane, and 2.8 for n-tetradecane. This may be due to the depletion of the more volatile components (e.g., n-decane) from the waste surface. 
Table 3-2. Tank 241-C-102 Upper Section -- Comparisons

\begin{tabular}{|c|c|c|c|c|c|}
\hline \multirow{2}{*}{ 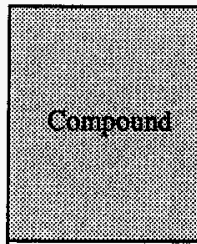 } & \multicolumn{3}{|c|}{ Eoro Sarmplas } & \multicolumn{2}{|c|}{ 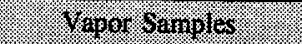 } \\
\hline & 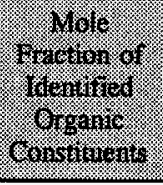 & 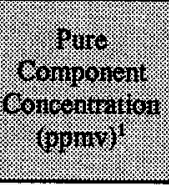 & 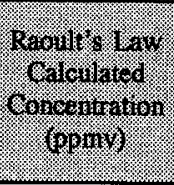 & 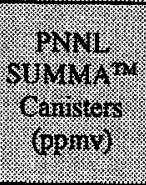 & $\frac{0}{(p p m i l}$ \\
\hline n-Decane & 0.015 & 1800 & 27 & 0.64 & 0.54 \\
\hline $\mathrm{n}$-Undecane & 0.068 & 600 & 41 & 1.62 & 1.40 \\
\hline n-Dodecane & 0.23 & 186 & 43 & 1.62 & 1.80 \\
\hline n-Tridecane & 0.37 & 56 & 21 & 1.46 & 1.30 \\
\hline n-Tetradecane & 0.17 & 17 & 2.9 & 0.50 & 1.02 \\
\hline $\begin{array}{l}\text { Tributyl } \\
\text { Phosphate }\end{array}$ & 0.15 & 6.3 & 0.95 & n.a. & 0.054 \\
\hline
\end{tabular}

n.a. $=$ not applicable

${ }^{1}$ Pure component concentrations were calculated at $25.8^{\circ} \mathrm{C}$ (the estimated tank 241-C-102 surface temperature) with Antoine equation constants given by Dean (1992) for n-decane, by Dreisbach (1959) for other alkanes, and by schultz and Navratil (1984) for TBP.

Historical data were used to predict that tank $241-\mathrm{C}-102$ probably contains NPHs and TBP in the waste, and both auger and vapor samples confirm this. The tank has been identified as one of seven that has a total effective surface area of NPHs in solution with TBP of greater than $1 \mathrm{~m}^{2}$ (Huckaby 1996).

TBP was found in both fractions of the auger sample, and at approximately the same concentrations. TBP was detected in vapor samples from tank 241-C-102, but because the sampling methods may have affected the measurement, the reported value of $0.054 \mathrm{ppmv}$ is thought to be lower than the actual value. Consequently, the agreement between the vapor and condensed-phase samples of TBP is only that it was detected in both. 
Table 3-3. Tank 241-C-102 Lower Section -- Comparisons

\begin{tabular}{|c|c|c|c|c|c|}
\hline \multirow[b]{2}{*}{ (6) } & \multicolumn{3}{|c|}{ 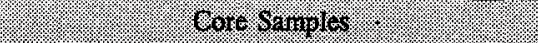 } & \multicolumn{2}{|c|}{ Wapor. S4mintes. } \\
\hline & 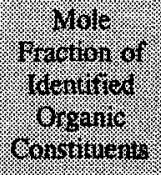 & 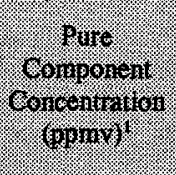 & 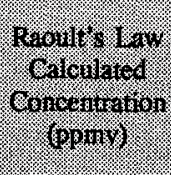 & 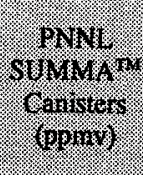 & 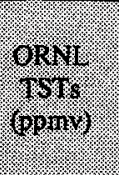 \\
\hline n-Decane & 0.015 & 1800 & 27 & 0.64 & 0.54 \\
\hline n-Undecane & 0.08 & 600 & 48 & 1.62 & 1.40 \\
\hline n-Dodecane & 0.25 & 186 & 47 & 1.62 & 1.80 \\
\hline n-Tridecane & 0.39 & 56 & 22 & 1.46 & 1.30 \\
\hline n-Tetradecane & 0.17 & 17 & 2.9 & 0.50 & 1.02 \\
\hline $\begin{array}{l}\text { Tributyl } \\
\text { Phosphate }\end{array}$ & 0.097 & 6.3 & 0.61 & n.a. & 0.054 \\
\hline
\end{tabular}

n.a. = not applicable

1 Pure component concentrations were calculated at $25.8^{\circ} \mathrm{C}$ (the estimated tank 241-C-102 surface temperature) with Antoine equation constants given by Dean (1992) for n-decane, by Dreisbach (1959) for other alkanes, and by Schultz and Navratil (1984) for TBP.

\subsection{REFERENCES}

Anderson, T. D., 1969, Organics in 102-C Tank, (internal letter to W. L. Godfrey, October 2), Rockwell Hanford Company, Richland, Washington.

Baldwin, J. H., R. J. Cash, W. I. Winters, L. Amato, and T. Tran, 1996, Tank Characterization Report for Single-Shell Tank 241-BY-108, WHC-SD-WM-ER-533, Rev. 0, Westinghouse Hanford Company, Richland, Washington.

Campbell, J. A., R. M. Bean, K. L. Wahl, G. M. Wong, K. E. Bell, K. B. Wehner, A. D. Rice, R. J. Ray, D. B. Bechtold, B. R. Wels, R. W. Schroeder, J. W. Ball, B. D. Valenzuela, J. M. Frye, S. L. Fitzgerald, P. P. Bachelor, B. Griffin, R. K. Fuller, A. B. Benally, and S. M. Parong, 1995, Analysis of Samples from Hanford Waste Tanks 241-C-102, 241-BY-108, and 241-C-103, PNL-10531, Pacific Northwest Laboratory, Richland, Washington. 
Cowley, W. L., and A. K. Postma, 1996, Analysis of Consequences of Postulated Solvent Fires in Hanford Site Waste Tanks, WHC-SD-WM-CN-032, Rev. OB, Westinghouse Hanford Company, Richland, Washington.

Carothers, K. G., 1988, Tank 103-C Transaction History - Post January 1976, (internal memorandum 13331-99-600 to D. A. Dodd, G. L. Dunford, G. N. Hanson, A. W. Lilly, and R. E. Van der Cook, September 22), Westinghouse Hanford Company, Richland, Washington.

Dean, J. A., 1992, Lange's Handbook of Chemistry, Fourteenth Edition, McGraw-Hill, Incorporated, New York, New York.

Dreisbach, R. R., 1959, Physical Properties of Chemical Compounds - II, Advances in Chemistry Series Number 22, American Chemical Society, Washington, D.C.

Huckaby, J. L., 1996, Technical Basis for ORGSCRN Spreadsheet, (Letter OT:073096 to J. E. Meacham, July 30), Pacific Northwest National Laboratory, Richland, Washington.

Huckaby, J. L., and B. R. Bratzel, 1995a, Tank 241-BY-112 Headspace Gas and Vapor Characterization Results for Samples Collected in November 1994, WHC-SD-WM-ER-441, Rev. 1A, Westinghouse Hanford Company, Richland, Washington.

Huckaby, J. L., and B. R. Bratzel, 1995b, Tank 241-BY-108 Headspace Gas and Vapor Characterization Results for Samples Collected in March 1994 and October 1994, WHC-SD-WM-ER-422, Rev. 2, Westinghouse Hanford Company, Richland, Washington.

Huckaby, J. L., and B. R. Bratzel, 1995c, Tank 241-BY-110 Headspace Gas and Vapor Characterization Results for Samples Collected in November 1994, WHC-SD-WM-ER-429, Rev. 2A, Westinghouse Hanford Company, Richland, Washington.

Huckaby, J. L., and B. R. Bratzel, 1995d, Tank 241-C-102 Headspace Gas and Vapor Characterization Results for Samples Collected in August 1994, WHC-SD-WM-ER-459, Rev. 1A, Westinghouse Hanford Company, Richland, Washington.

Huckaby, J. L., J. L. Edwards, J. C. Evans, J. S. Fruchter, J. L. Julya, K. B. Olsen, K. H. Pool, B. L. Thomas, K. L. Silvers, L. Jensen, L. L. Buckley, S. R. Wilmarth, and L. D. Pennington, 1996, Comparison of Vapor Sampling System (VSS) and In Situ Vapor Sampling (ISVS) Methods on Tanks C-107, BY-108, and S-102, PNNL-11186, Pacific Northwest National Laboratory, Richland, Washington. 
Jenkins, R. A., A. B. Dindal, C. E. Higgins, C. Y. Ma, M. A. Palauski, J. T. Skeen, and C. K. Bayne, 1995a, Analysis of Tank 241-TY-104 Headspace Samples Collected via In-Situ Sampling, ORNL-CASD-FR-241TY104ISS, Rev. 0, Oak Ridge National Laboratory, Oak Ridge, Tennessee.

Jenkins, R. A., A. B. Dindal, C. E. Higgins, C. Y. Ma, M. A. Palauski, J. T. Skeen, and C. K. Bayne, 1995b, Analysis of Tank 241-C-102 Headspace Components, ORNL-CASD-FR-241C102.95, Rev. 1, Oak Ridge National Laboratory, Oak Ridge, Tennessee.

Mahon, R. D., C. M. Jones, and M. S. Story, 1994, Evaluation of the Capabilities and Use of the Vapor Sampling System for Tank Headspace Sampling and Characterization, WHC-SD-WM-RPT-094, Rev. 0, Westinghouse Hanford Company, Richland, Washington.

Schultz, W. W., 1968, Characterization of the Organic Material in the 112 BY Tank, BNWL-CC-1517, Pacific Northwest Laboratory, Richland, Washington.

Schultz, W. W., and J. D. Navratil, 1984, Science and Technology of Tributyl Phosphate; Volume 1, Synthesis, Properties, Reactions and Analysis, CRC Press, Boca Raton, Florida.

Sederburg, J. P., and J. A. Reddick, 1994, TBP and Diluent Mass Balances in the PUREX Plant at Hanford 1955 - 1991, WHC-MR-0483, Westinghouse Hanford Company, Richland, Washington.

Simpson, B. C., R. D. Cromar, and R. D. Schreiber, 1996, Tank Characterization Report for Single-Shell Tank 241-BY-110, WHC-SD-WM-ER-591, Rev. 0, Westinghouse Hanford Company, Richland, Washington.

WHC, 1995a, Vapor and Gas Sampling of Single-Shell Tank 241-BY-108 Using the Vapor Sampling System, WHC-SD-WM-RPT-121, Rev. 0, Westinghouse Hanford Company, Richland, Washington.

WHC, 1995b, Vapor and Gas Sampling of Single-Shell Tank 24I-BY-110 Using the Vapor Sampling System, WHC-SD-WM-RPT-123, Rev. 0, Westinghouse Hanford Company, Richland, Washington.

WHC, 1995c, Vapor and Gas Sampling of Single-Shell Tank 241-C-102 Using the Vapor Sampling System, WHC-SD-WM-RPT-127, Rev. 0, Westinghouse Hanford Company, Richland, Washington. 


\section{DISTRIBUTION}

Number of copies

OFFSITE

1

G \& P Consulting. Inc.

3640 Ballard Road

Dallas, OR 97338

Arlin K. Postma

1

Nuclear Consulting Services. Inc.

P.O. Box 29151

Columbus, OH 43229-0151

J. Louis Kovach

\section{ONSITE}

Pacific Northwest National Laboratory

J. W. Brothers

K9-20

J. A. Glissmeyer

K6-80

R. T. Hallen

P8-38

J. L. Huckaby

K6-80

Hanford Technical Library

P8-55

9

Westinghouse Hanford Company

H. Babad

S7-30

R. J. Cash

S7-14

J. M. Grigsby

A3-37

N. W. Kirch

R2-11

J. E. Meacham (2)

S7-14

L. A. Stauffer

R2-11

Central Files

A3-88

DPC

A3-94 
WHC-EP-0919

This page intentionally left blank.

Distr-2 